\title{
HER2 Aberrations in Non-Small Cell Lung Cancer: From Pathophysiology to Targeted Therapy
}

\author{
Ioannis A. Vathiotis ${ }^{1,2, * \mathbb{1}}$, Andriani Charpidou ${ }^{1}$, Niki Gavrielatou ${ }^{2}$ and Konstantinos N. Syrigos ${ }^{1}$ \\ 1 Section of Medical Oncology, Third Department of Internal Medicine, National and Kapodistrian University \\ of Athens, 11527 Athens, Greece; dcharpidou@yahoo.gr (A.C.); ksyrigos@med.uoa.gr (K.N.S.) \\ 2 Department of Pathology, Yale School of Medicine, New Haven, CT 06510, USA; niki.gavrielatou@yale.edu \\ * Correspondence: ioannis.vathiotis@yale.edu; Tel.: +30-6948822683
}

Citation: Vathiotis, I.A.; Charpidou,

A.; Gavrielatou, N.; Syrigos, K.N.

HER2 Aberrations in Non-Small Cell Lung Cancer: From Pathophysiology to Targeted Therapy. Pharmaceuticals 2021, 14, 1300. https://doi.org/ $10.3390 / \mathrm{ph} 14121300$

Academic Editor: Fu-Gen Wu

Received: 30 October 2021

Accepted: 10 December 2021

Published: 14 December 2021

Publisher's Note: MDPI stays neutral with regard to jurisdictional claims in published maps and institutional affiliations.

Copyright: () 2021 by the authors. Licensee MDPI, Basel, Switzerland. This article is an open access article distributed under the terms and conditions of the Creative Commons Attribution (CC BY) license (https:// creativecommons.org/licenses/by/ $4.0 /)$.

\begin{abstract}
While human epidermal growth factor receptor 2 (HER2) aberrations have long been described in patients with non-small cell lung cancer (NSCLC), they have only recently been effectively targeted. Unlike patients with breast cancer, NSCLC patients can harbor either HER2-activating mutations or HER2 amplification coupled with protein overexpression. The latter has also been the case for patients with acquired resistance to epidermal growth factor receptor (EGFR) tyrosine kinase inhibitors (TKIs). As preclinical data continue to accumulate, clinical trials evaluating novel agents that target HER2 have produced promising preliminary results. Here, we review existing data on HER2 aberrations in NSCLC. Starting from HER2 biology in normal and disease processes, we summarize discrepancies in HER2 diagnostic assays between breast cancer and NSCLC. Finally, to dissect the therapeutic implications of HER2-activating mutations versus gene amplification and/or protein overexpression, we present data from prospective clinical trials that have employed distinct classes of agents to target HER2 in patients with NSCLC.
\end{abstract}

Keywords: NSCLC; HER2; ERBB2; trastuzumab

\section{Introduction}

First identified in the 1980s as the product of neu oncogene in rodents by Robert Weinberg's group, human epidermal growth factor receptor 2 (HER2; also known as ErbB2 or CD340) is one of the four members of the ErbB family of receptor tyrosine kinases (RTKs), along with ErbB1 (epidermal growth factor receptor (EGFR), HER1), ErbB3 (HER3), and ErbB4 (HER4) [1]. The initial discovery of the ErbB2 gene in a rat neuro/glioblastoma model in 1984 was soon followed by the uncovering of its implication in breast cancer pathophysiology and prognosis, laying the groundwork for novel directions in breast cancer treatment and commencing the era of targeted therapy in modern oncology [2,3].

HER2 activation has been shown to drive oncogenic downstream signaling, promoting tumor cell proliferation and survival [4]. Consequently, HER2 targeting has been extensively investigated as a potential therapeutic strategy, demonstrating efficacy across a multitude of solid tumors. Identified in $15-20 \%$ of all breast cancers, HER2 protein overexpression and/or gene amplification has been shown to characterize an aggressive disease subgroup with high invasive and metastatic potential, resistance to hormonal and chemotherapy regimens, and poor outcome [5,6]. In 1998, the first FDA approval of trastuzumab, a monoclonal antibody (mAb) against HER2, for the treatment of metastatic breast cancer marked the beginning of the upturn of what had been a dismal natural course of HER2-positive disease [7,8]. Since then, several HER2-targeting agents, including mAbs, tyrosine kinase inhibitors (TKIs), signal transduction inhibitors, and lately, antibody-drug conjugates (ADCs) have shown preclinical and/or clinical efficacy, spanning all disease stages and treatment settings of HER2-positive breast cancer. Accordingly, gastric and gastroesophageal junction tumors, which demonstrate HER2 positivity in approximately $20 \%$ of the cases, became the second malignancy for which trastuzumab was added to standard 
of care, first-line chemotherapy regimens [9]. Additionally, HER2 overexpression and/or gene amplification of diverse degree has also been described in several other solid tumors including biliary tract, colon, bladder, ovarian, endometrial, head and neck and non-small cell lung cancer (NSCLC) [10]. However, targeting HER2 aberrations with conventional anti-HER2 agents has failed to replicate their breast cancer efficacy, indicating the extent of biological diversity conferred by alternative HER2 aberrations, which prevail in distinct malignancies [11,12].

Springing from the recent Food and Drug Administration (FDA) therapy designations of two agents targeting HER2, we review available data on HER2 aberrations in NSCLC. Based on the biology of this pathway in normal and disease processes, we sought to describe discrepancies in HER2 diagnostic assays that could potentially explain discordances in response to distinct classes of agents targeting HER2 in patients with NSCLC.

\section{Biology}

Physiology. All four ErbB receptors constitute type I transmembrane growth factor RTKs with high structural homology. They consist of an extracellular N-terminal region, which acts as their ligand-binding site, a transmembrane region, and an intracellular region, which is composed of a juxtamembrane, a kinase catalytic, and a carboxy-terminal domain $[13,14]$. Under physiologic conditions, ligand binding results in either homodimerization or heterodimerization, which is the required initial step for activation, and it sequentially triggers the transphosphorylation of intracellular tyrosine residues and stimulates multiple downstream signaling pathways related to cell growth, differentiation, survival, and invasion [15]. Several molecules have been identified as soluble ligands with specific binding capacity to one or more ErbB receptors; ligand-receptor specificity has been implicated in the elicitation of distinct signaling pathways, which is an effect linked to variable dimer formation and tyrosine residue phosphorylation [16]. In contrast with the other ErbB family members, HER2 is characterized as a ligand-independent receptor, as no molecule has been described to bind to its extracellular domain, which may retain an active conformation, irrespective of the presence of ligand $[17,18]$. Interestingly, HER2, which has the highest tyrosine kinase activity, represents the preferred partner for heterodimerization with any ErbB family member, while HER2 pairing with HER3, which in turn lacks tyrosine kinase activity completely, displays the highest signaling potency, suggesting a complementary interaction of HER2 and HER3 $[19,20]$.

Pathophysiology. HER2 protein overexpression, which occurs under unknown biological mechanisms, and/or HER2 gene amplification or transcriptional dysregulation results in up to 100-fold increase in cell-surface HER2 and consequently drives HER2-mediated tumorigenesis [21]. The increased presence of HER2 on the cell surface results in an increased formation of HER2-containing heterodimers, which is a process that has been shown to alter cell polarity and adhesion and lead to the activation of several oncogenic signaling pathways including MAPK, PI3K/Akt, phospholipase- $\mathrm{C} \gamma$, protein kinase $\mathrm{C}$, and the Janus kinase (Jak-STAT) [22]. Although somatic mutations in the extracellular or transmembrane domain of the neu gene (the rodent analogue of HER2) have been reported in preclinical models, human HER2-positive breast tumors consistently demonstrate overexpression of wild-type HER2 [23].

While breast cancer pathogenesis predominantly depends on HER2 overexpression caused by gene amplification, HER2-associated lung tumors may exhibit either HER2 overexpression or somatic mutations [24,25]. The absence of amplification and mutation overlap in NSCLC has been proposed as an explanation for the observed poor outcomes of classic anti-HER2 agents employed in breast cancer therapeutics [26,27]. The breach between the biological impact of HER2 amplification versus mutation is further highlighted by the observation that the former has been associated with improved response to EGFR inhibition in NSCLC, whereas the latter has been linked to in vitro resistance to EGFR tyrosine kinase inhibitors (TKIs) [28,29]. Moreover, in contrast with HER2 mutations, HER2 amplification has been identified as a mechanism of acquired resistance to EGFR TKIs [30]. 
The majority of HER2 mutations in NSCLC comprise insertions or missense mutations located in exons 18-20 and similarly to mutations in EGFR, which primarily involve exons 18-21, they affect the $\alpha$ C-helix and loop part of the kinase domain (Figure 1) [31,32]. The most commonly described HER2 mutations in NSCLC are in-frame insertions in exon 20, which can act as proliferative drivers through constitutive activation of the receptor and downstream induction of PI3K/Akt and MEK oncogenic pathways [33]. The in-frame YVMA insertion at residue 776 of exon 20 represents the most frequently detected HER2 variant (80-90\% of all HER2 mutations) and has been associated with more potent catalytic kinase activity and increased transforming and anti-apoptotic potential in comparison with the wild-type HER2 gene [25,34,35]. Notably, YVMA insertion has been identified as an early event lung adenocarcinoma tumorigenesis [36]. Apart from kinase domain alterations, a germline (G660D) and a somatic (V659E) mutation of the transmembrane domain have also been identified as lung adenocarcinoma drivers through the activation of Akt signaling [37]. Extracellular domain mutations have also been described in NSCLC, and specifically, G309E and S310F have demonstrated increased oncogenic activity through high C-terminal phosphorylation and dimerization potential [38].

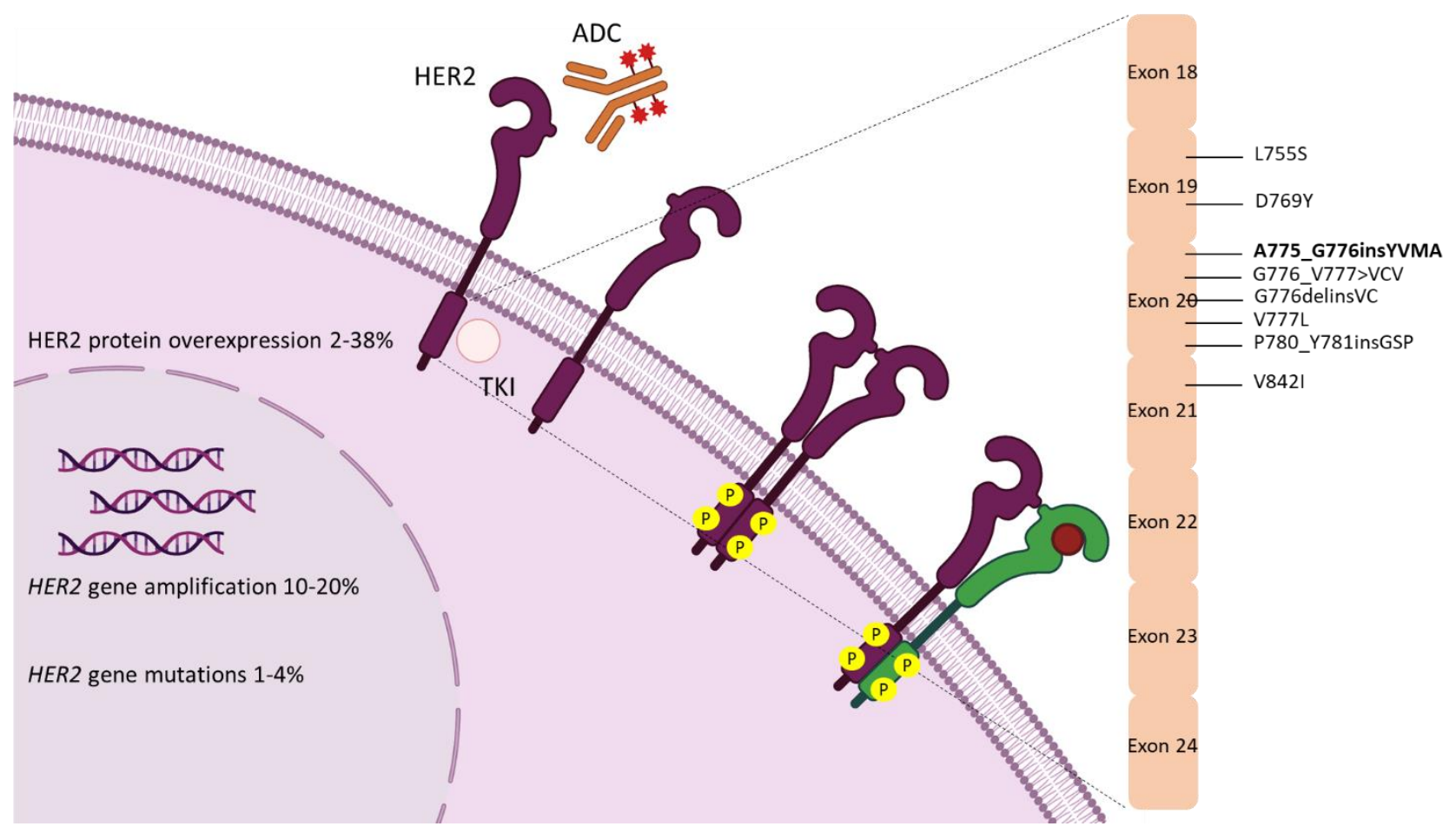

Figure 1. HER2 aberrations in non-small cell lung cancer. ADC, antibody-drug conjugate; TKI, tyrosine kinase inhibitor.

\section{Epidemiology}

De novo HER2 aberrations are mutually exclusive with other oncogenic driver alterations, such as mutations in KRAS, EGFR, etc. [25]. They most commonly occur in patients with lung adenocarcinoma; HER2 mutations and amplifications have been reported in 1-4\% and $2-5 \%$ of patients with lung adenocarcinoma, respectively $[25,32,34,39,40]$. Mutations in HER2 are more frequent in female patients and never-smokers; HER2 amplification and concomitant protein overexpression have been linked with male sex and cigarette smoking [41,42]. No association with HER2 aberrations and age has been documented. HER2 amplification also plays a significant role in EGFR-mutant NSCLC, emerging as a mechanism of acquired resistance to EGFR TKIs in $10-12 \%$ of the cases [43-45]. 


\section{HER2 Diagnostic Assays}

Currently, the two approved techniques for HER2 status evaluation in breast cancer are immunohistochemistry (IHC) and fluorescence in situ hybridization (FISH), which detect HER2 protein overexpression and HER2 gene amplification (defined as an increased copy number of the chromosome 17 region [17q12q21]), respectively. In brief, according to the updated 2018 American Society of Clinical Oncology (ASCO)/College of American Pathologists (CAP) guidelines, HER2 positivity is defined either as $>10 \%$ of tumors cells showing complete, strong HER2 membrane staining (3+) by IHC, or as the detection of a HER2:CEP17 ratio of $\geq 2$ and/or HER2 gene copy number $\geq 6$ by FISH. In diagnostically ambiguous cases, where weak to moderate membrane staining is observed in $>10 \%$ of tumor cells (termed IHC2+), retest of the same specimen with FISH or testing of a new specimen with either IHC or FISH is required [46]. Similar recommendations have been made for gastroesophageal adenocarcinoma, with the exception that due to characteristic histology, the percentage of tumor cells that exhibit basolateral or lateral, rather than complete, membranous staining is calculated to define HER2 positivity by IHC [47]. It should be noted that the previously described cutoffs are closely linked to the clinical indication for trastuzumab administration, as the mechanism of action and consequently the efficacy of the drug is based on HER2 protein overexpression [48].

Regarding NSCLC, no official guidelines have been developed for the assessment of HER2 positivity, and as a result, the evaluation of gene amplification and/or protein overexpression in clinical trials has been, until recently, performed via extrapolation from breast and gastric cancer. Notably, HER2 IHC staining in NSCLC exhibits better analogy with gastric rather than breast cancer staining patterns [49]. Importantly, as far as NSCLC is concerned, "HER2-mutant" is becoming a considerably more relevant term than "HER2-positive". Moreover, HER2 amplification and/or overexpression have failed to demonstrate any clear or consistent association with the presence of mutations in HER2 across several studies $[25,27,50,51]$. Poziotinib recent fast track therapy designation was granted based on the presence of HER2 exon 20 mutations, which were documented either in tissue by next-generation sequencing (NGS) with Oncomine ${ }^{\mathrm{TM}}$ Comprehensive Assay (Thermo Fisher Scientific, Waltham, MA, USA) or FoundationOne ${ }^{\circledR}$ Assay (Foundation Medicine, Cambridge, MA, USA) or in plasma using Guardant $360^{\circledR}$ Assay (Guardant Health, Redwood City, CA, USA) [52]. In the Destiny-Lung01 trial, which led to the breakthrough therapy designation of trastuzumab-deruxtecan for HER2-mutant NSCLC, HER2 mutation status was determined again by a CLIA standards local NGS method or equivalent and then centrally confirmed with the Oncomine ${ }^{\mathrm{TM}} \mathrm{Dx}$ Target Test (Thermo Fisher Scientific, Waltham, MA, USA). Inclusion criteria were met for patients harboring a known HER2-activating mutation of the kinase (exons 18-20), juxtamembrane (exon 17), or extracellular domain (exon 8) [53].

\section{Targeting HER2 in NSCLC}

Non-selective tyrosine kinase inhibitors. The first attempts to target HER2 in patients with NSCLC were made using non-selective TKIs already approved for the treatment of EGFRpositive disease. In 2015, De Grève et al. assessed the efficacy of the quinazoline-based, irreversible pan-HER TKI afatinib in pretreated patients with advanced or metastatic NSCLC harboring HER2 exon 20 mutations (Table 1) [54]. Neither complete (CR) nor partial responses (PR) were reported. However, stable disease (SD) was documented in five out of seven study participants, accounting for a disease control rate (DCR) of $71.4 \%$. Subsequently, afatinib was evaluated as part of a named patient use program that enrolled 28 heavily pretreated patients with advanced NSCLC and activating HER2 mutations determined by local testing [55]. Among 16 patients with available tumor response data, three PR were documented, conveying an objective response rate (ORR) of $18.8 \%$ and DCR of $68.8 \%$. Notably, the efficacy of afatinib was higher in patients harboring the A775_G776insYVMA mutation, with an ORR of $33.3 \%$ and DCR of $100 \%$. The NICHE phase II study investigated the potential of afatinib to control disease in patients with HER2- 
mutant disease that had progressed during or after platinum-based chemotherapy [56]. Only one patient achieved PR, while ORR and DCR were $7.7 \%$ and $53.8 \%$, respectively, resulting in the accrual to stop at 13 patients. Median progression-free survival (PFS) was 15.9 weeks, and median overall survival (OS) was 56.0 weeks. Lately, the efficacy of afatinib was evaluated in the setting of another phase II trial conducted in previously treated Asian patients with HER2-mutant NSCLC [57]. This study consisted of two parts: in Part A, patients were treated with afatinib monotherapy until disease progression or unacceptable toxicity, while Part B were to enroll patients who showed clinical benefit in Part A (for more than 12 weeks) and continue treatment with afatinib coupled with paclitaxel. While DCR was $61.1 \%$, none of the 18 enrolled patients achieved a PR. Median PFS and OS were 2.8 months and 10.0 months, respectively. Due to the lack of study participants meeting the inclusion criteria for Part B as well as the slow rate of recruitment, the study was terminated early. In all the above studies, adverse events (AE) were generally consistent with the toxicity profile of afatinib, with the most common being diarrhea, rash/acne, and stomatitis.

Dacomitinib is another irreversible HER family blocker that has shown efficacy in EGFR-mutant NSCLC $[58,59]$. The antitumor activity of dacomitinib was evaluated in a prespecified cohort of a phase II study, which included patients with advanced or metastatic NSCLC and HER2 mutations $(n=26)$ or amplification $(n=4)$ [60]. ORR was $11.5 \%$ in patients with $H E R 2$ mutations but $0 \%$ in those with amplifications. In patients with HER2-mutant tumors, the median PFS and OS were 3.0 and 9.0 months, respectively. Interestingly, exon 20 mutations did not correlate with gene amplification. In addition, no responses were observed in the presence of the most common HER2 exon 20 alteration, namely A775_G776insYVMA. Treatment-related AEs occurred in all study participants; the most common $\mathrm{AE}$ was diarrhea, which was documented in $90.0 \%$ of the patients. Dacomitinib toxicity led to dose reduction or discontinuation in $17.0 \%$ and $13.0 \%$ of the patients, respectively.

The in vitro activity of HER-targeted agents across different HER2 mutations has been evaluated in preclinical NSCLC models, with both afatinib and neratinib exhibiting significantly increased efficacy toward the A775_G776insYVMA exon 20 insertion [61]. Furthermore, the combination of neratinib and trastuzumab was more effective than neratinib monotherapy, resulting in robust inhibition of HER2 as well as downstream signaling in vivo [62]. Twenty-six patients with advanced NSCLC and concomitant HER2 aberrations received neratinib in the setting of the SUMMIT phase II basket study [63]. Despite the low ORR observed (3.8\%, one PR in a case with L755S kinase domain missense mutation), DCR reached $42.3 \%$. The median PFS was 5.5 months, with six patients remaining on treatment for more than a year, suggesting that neratinib may still have a positive impact on the natural course of refractory NSCLC cases. The most common AEs of neratinib were diarrhea $(73.8 \%)$, nausea $(43.3 \%)$, and vomiting $(41.1 \%)$.

Selective tyrosine kinase inhibitors. Non-selective pan-HER TKIs have demonstrated moderate antitumor activity, achieving sporadic responses against exon 20 insertions that represent the most common genomic aberration in HER2-mutant NSCLC. Threedimensional modeling revealed that such insertions induce a constitutively active conformation, which prevents the binding of non-covalent HER2 inhibitors. Additionally, exon 20 insertions appear to confine the drug-binding pocket, hampering the binding of large, rigid inhibitors and the size of the insertion may affect drug sensitivity; single amino acid insertions are more likely to respond to, previously mentioned, non-selective TKIs (i.e., afatinib) [64]. In this regard, poziotinib has been shown to possess certain structural features, including relatively small size, increased halogenation, and flexibility, that could overcome insertion-induced changes within the drug-binding pocket of exon 20. Poziotinib had an average IC50 value of $1.9 \mathrm{nM}$ in Ba/F3 cell lines with an HER2 exon 20 insertion, making it six times more potent than afatinib in vitro. The predicted efficacy of poziotinib was also confirmed in vivo using NSCLC tumor models that bore the previously described genomic alterations. Early results of poziotinib from phase I trials justified its further de- 
velopment in patients with EGFR-mutant as well as HER2-mutant cancers [65]. Robichaux et al. conducted a phase II study in 12 heavily pretreated NSCLC patients harboring HER2 exon 20 insertions with promising preliminary results; ORR was 41.7\% (5 PR), DCR was $83.3 \%$, and median PFS was 5.6 months [66]. All study participants harbored either the Y772dupYVMA or G778dupGSP insertions. The most common treatment-related AE was rash, which occurred in all study participants and was grade 3 or 4 in seven cases. Other common AEs were diarrhea and paronychia, which were mainly grade 1 or 2 . Eight patients on poziotinib $(66.7 \%)$ required at least one dose reduction, but no patient had to discontinue treatment due to poziotinib-related toxicity. Similar results were reported from another investigator-initiated, single-center study that enrolled 30 NSCLC patients with HER2 exon 20 mutations [52]. ORR for poziotinib was $26.7 \%$ with responses detected across different HER2 exon 20 mutation subtypes. The median PFS reached 5.5 months, and median OS reached 15 months. Matters of safety and efficacy of poziotinib were also evaluated in ZENITH20, a multi-cohort phase II clinical trial, including both previously treated and treatment naïve patients with HER2 exon 20 mutations (cohorts 2 and 4, respectively) [67]. In March 2021, the FDA granted "fast-track designation" to poziotinib for use in previously treated patients with HER2 exon 20 mutations based on preliminary results from the ZENITH20 study; ORR was $27.8 \%$, DCR was $70.0 \%$ and median PFS was 5.5 months [68]. Updated results from cohort 4 also suggested promising antitumor activity among treatment-naïve patients with an ORR of $43.8 \%$, DCR of $75.0 \%$, and median PFS of 5.6 months [69]. The toxicity profile of poziotinib was consistent with the previous studies leading to dose interruptions, dose reductions, and treatment discontinuation in $88.0 \%$, $76.0 \%$, and $12.0 \%$ of patients, respectively. Lately, data from the poziotinib expanded access program came to confirm the phase II results; the ORR was 30.0\% (higher in patients with HER2-mutant tumors), DCR was $80.0 \%$, median PFS was 5.6 months, and median OS was 9.5 months [70].

However, heterogeneity among HER2 exon 20 insertions affects sensitivity to antiHER2 TKIs, and C805S insertion has been shown to mediate acquired drug resistance in initially sensitive HER2 exon 20 insertion models [71]. Using patient-derived tumor organoids as well as xenografts, Wang et al. demonstrated the enhanced antitumor activity of pyrotinib [72]. Pyrotinib also produced promising preliminary results in 15 previously treated patients with an HER2-mutant NSCLC. The ORR was 53.3\% (8 PR) and DCR was $73.3 \%$ with a median PFS of 6.4 months. Notably, pyrotinib was effective against A775_G776insYVMA, G776C, G776>VC, and L755P but not the G776>IC mutation. Subsequently, pyrotinib was evaluated in a larger phase II trial that enrolled 60 previously treated stage IIIB-IV NSCLC patients with HER2-mutant tumors [73]. The ORR and DCR observed were $30.0 \%$ and $85.0 \%$, respectively. Importantly, the administration of pyrotinib benefited all different patient subcategories, including patients with brain metastases at baseline and heavily pretreated individuals. The median PFS reached 6.9 months and the median OS reached 14.4 months. As far as safety is concerned, the most common treatment-related AE was diarrhea, as reported in $91.7 \%$ of the patients. Other treatment-related toxicities included elevations in serum creatinine and transaminases.

Tarloxotinib is a hypoxia-activated prodrug of an irreversible pan-HER TKI [74]. Although the prodrug has feeble inhibitory activity in oxygenated normal tissues, sparing them from wild-type HER inhibition, it can be converted to the active metabolite (tarloxotinib-E) in the hypoxic tumor microenvironment. Tarloxotinib-E-induced suppression of EGFR, HER2, and HER4 signaling has been shown to impede tumor cell proliferation in vitro, resulting in tumor regression in multiple murine xenograft models. Pharmacokinetic analysis confirmed significantly increased concentrations of tarloxotinib-E in tumor tissue compared with plasma or normal skin. The RAIN-701 phase II trial enrolled patients with advanced NSCLC harboring HER2 activating mutations (cohort B) [75]. Among nine evaluable patients, two experienced PR and four had SD, accounting for ORR and DCR of $22.2 \%$ and $66.7 \%$, respectively. The most common treatment-related AEs were QTc prolongation, rash, and diarrhea occurring in $60.9 \%, 43.5 \%$, and $21.7 \%$, respectively. 


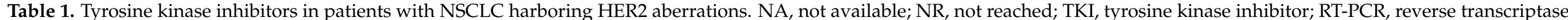
polymerase chain reaction; NGS, next-generation sequencing; ORR, objective response rate; PFS, progression-free survival; OS, overall survival; AE, adverse event.

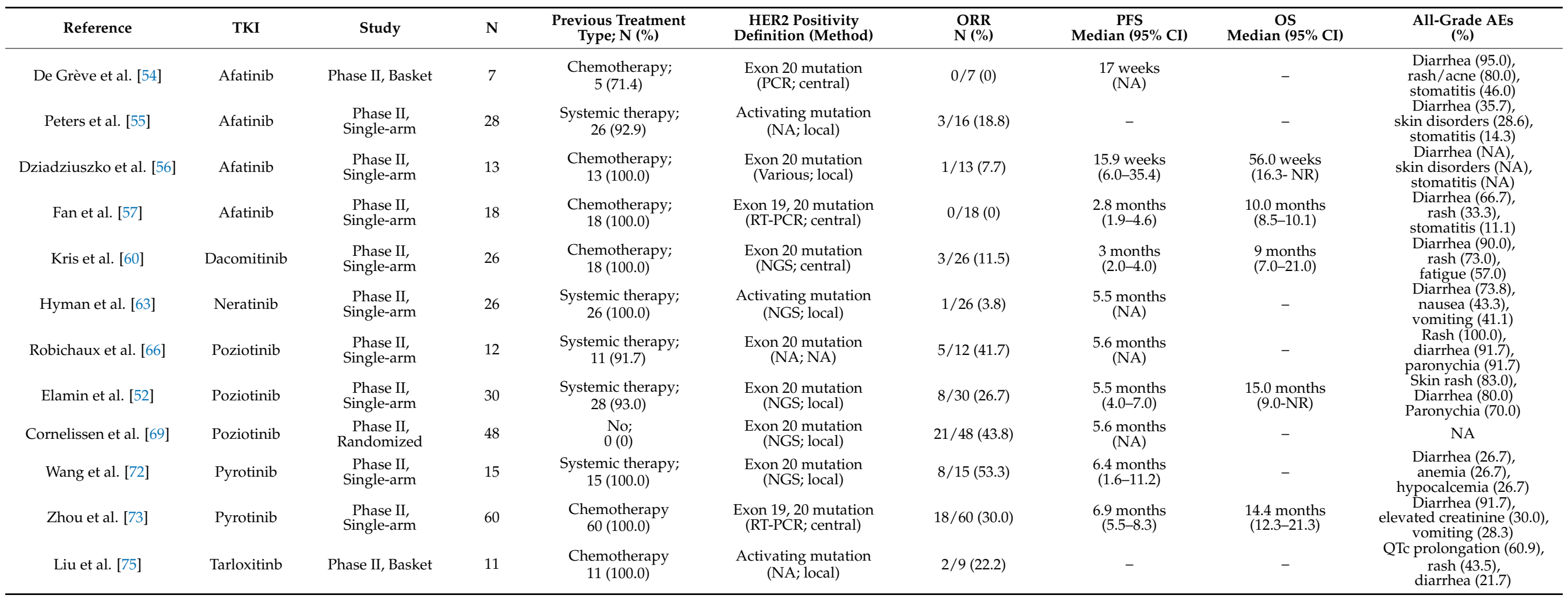


Mobocertinib is a novel small-molecule TKI designed against exon 20 insertions; in a phase I/II clinical trial, mobocertinib showed promising antitumor activity in previously treated NSCLC patients with EGFR exon 20 insertions, resulting in "breakthrough therapy designation" by the U.S. Food and Drug Administration (FDA) [76,77]. Preclinical data indicate that mobocertinib is highly selective, as it possesses the lowest HER2 exon 20 insertion/wild-type EGFR IC50 ratio. In addition, tumors harboring the G776>VC insertion exhibited dramatic and more prolonged responses compared with YVMA insertion-positive tumors. In addition, mobocertinib appeared to act synergistically with T-DM1 in YVMA insertion-positive lung cancer.

Monoclonal antibodies. Trastuzumab is a humanized IgG1 kappa mAb that binds to the extracellular domain of HER2. It interferes with HER2 signaling via several mechanisms, including inhibition of receptor dimerization, prevention of extracellular domain shedding, endocytotic destruction of the receptor, and antibody-dependent cell-mediated cytotoxicity [78]. Based on the paradigm of breast cancer, most clinical trials evaluating trastuzumab in patients with NSCLC have required evidence of protein overexpression or gene amplification rather than the detection of specific HER2 gene mutations. HOT1303-B trial assessed trastuzumab monotherapy in 10 previously treated patients with NSCLC and HER2-altered tumors, which were defined as IHC3+, IHC 2+/FISH+, and/or by the presence of activating mutations (Table 2) [79]. Although no responses were documented, DCR was 70.0\%, and the median PFS reached 5.2 months. A larger, randomized phase II trial in 101 treatment-naïve patients with NSCLC, showed that the addition of trastuzumab to cisplatin and gemcitabine was beneficial in a small subgroup of IHC3+ or FISH+ cases (six patients; ORR of $83.3 \%$ and median PFS of 8.5 months) but not in the overall population [80]. Similar results were observed in another phase II single-arm study evaluating the combination of paclitaxel, carboplatin, and trastuzumab; ORR was $24.5 \%$, median PFS was 3.3 months, and median OS was 10.1 months [81]. Available data from the MyPathway phase II basket trial demonstrated that dual HER2 blockade with trastuzumab and pertuzumab was effective in patients harboring HER2 exon 20 mutations as well as those having HER2 amplification or overexpression (ORR was $21.4 \%$ and $15.4 \%$, respectively; DCR was $46.2 \%$ and $25.0 \%$, respectively) [82].

Antibody-drug conjugates. Trastuzumab-emtansine (T-DM1) is an ADC that consists of an anti-HER2 agent (trastuzumab) and a cytotoxic microtubule (emtansine; DM1). T-DM1 employs receptor-mediated endocytosis to enter HER2-positive cells; DM1 is released after proteolytic degradation of the antibody moiety in the target cell lysosomes [83]. The first results of T-DM1 in NSCLC were derived from a small phase II trial that enrolled 15 previously treated patients [84]. T-DM1 demonstrated minimal antitumor activity with an ORR of $6.7 \%$, DCR of $71.4 \%$, and median PFS and OS times of 2.0 months and 10.9 months, respectively. Notably, no responses were obtained in patients with HER2-amplified or HER2-overexpressing tumors. However, results from a subsequent phase II basket trial enrolling 49 previously treated patients (including 11 patients with HER2 amplification and 28 patients with HER2 mutations) revealed that treatment with T-DM1 might achieve ORR as high as $51.0 \%$ [85,86]. Median PFS for the study cohort was 5.0 months. Although study data indicated that the presence of HER2 mutations detected by NGS was not concordant with gene amplification or protein overexpression by IHC and FISH, responses to T-DM1 were comparable between these subgroups. Peters et al. assessed the efficacy of T-DM1 in 49 previously treated NSCLC patients with HER2 overexpression (i.e., IHC2+ or $\mathrm{IHC} 3+)$ [87]. Although no responses were seen in the IHC2+ cohort, ORR was $20.0 \%$ in the IHC3+ cohort; DCR was $27.6 \%$ and $40.0 \%$ in the IHC2+ and IHC3+ cohorts, respectively. Median PFS and OS were comparable in the IHC 2+ and 3+ cohorts (median PFS was 2.6 months and 2.7 months, respectively and median OS was 12.2 months and 15.3 months, respectively). The toxicity profile of T-DM1 was consistent with previous trials in patients with breast cancer.

Trastuzumab-deruxtecan (T-Dxd) is a newer HER2-targeting ADC composed of trastuzumab, which is an enzymatically cleavable peptide linker and a topoisomerase 
I inhibitor (MAAA-1181). T-Dxd is a stable and homogeneous molecule with increased membrane permeability and a higher drug-to-antibody ratio compared with other available ADCs. This enables a steady delivery of the topoisomerase I inhibitor even in HER2-low expressing conditions [88]. The first results of T-Dxd in heavily pretreated (median of four prior anticancer regimens) patients with NSCLC were impressive; ORR was 55.6\% (6/11 PR), and DCR was 77.8\% with a median PFS of 11.3 months [89]. Patients with HER2-mutant non-small cell lung tumors had more pronounced treatment benefit than those without documented mutations, regardless of IHC/FISH status; among 11 patients harboring the HER 2 mutation, the ORR and DCR were $72.7 \%$ and $90.9 \%$, respectively. The DESTINY-Lung01 phase II trial evaluated the efficacy of T-Dxd in two cohorts of NSCLC patients; cohort 1 contained patients with HER2 overexpression (i.e., IHC2+ or IHC $3+$ ), while cohort 2 contained patients with HER2 mutations. Results from cohort 1 showed an ORR of $24.5 \%$ with a median PFS of 5.4 months. Notably, response rates did not differ according to HER2 IHC expression levels. Recently published results from cohort 2 indicated enhanced antitumor efficacy among patients with HER2-mutant tumors [53]. Among 91 patients, the ORR reached 54.9\% with a DCR of $92.3 \%$. The median PFS and OS were 8.2 months and 17.8 months, respectively. The most common treatment-related AEs were gastrointestinal and hematologic, while pneumonitis was reported in about $12.0 \%$ of the study participants. According to these data, trastuzumab-deruxtecan received "breakthrough therapy designation" from the FDA for the treatment of patients with metastatic NSCLC whose tumors have a HER2 mutation and with disease progression on or after platinum-based therapy.

Immune checkpoint blockade. The presence of driver alterations in NSCLC has been associated with a "cold" immune microenvironment and the limited clinical efficacy of immune checkpoint inhibitors [90-92]. Among different driver alterations, mutations in HER2 have been linked with the lowest levels of PD-L1 expression, which are comparable to those of tumors harboring either classic or exon 20 EGFR mutations; the prevalence of positive and high PD-L1 expression in HER2-mutant disease was about $50.0 \%$ and $20.0 \%$, respectively. Accordingly, NSCLC tumors with HER2 mutations have in general low tumor mutational burden (TMB), with median TMB values $<3$ mut $/ \mathrm{Mb}$.

As far as efficacy is concerned, available data are scarce and extracted solely from retrospective studies (Table 3). NSCLC patients with HER2-mutant tumors that receive immunotherapy beyond the first line of treatment generally exhibit single-digit ORRs [93-97]. For such patients, median PFS and OS fall within the range of 2 months and 20 months, respectively. Recently, Saalfeld et al. reported on the efficacy of immunotherapy (either alone or combined with chemotherapy) in patients with HER2-mutant NSCLC comparing patients in the first versus subsequent lines of therapy [98]. Using a retrospective cohort of 61 patients, they found that first-line chemoimmunotherapy may achieve response rates comparable to those of unselected NSCLC patients; among patients receiving firstline chemoimmunotherapy, the ORR was $52.4 \%$ and the median PFS reached 6.0 months. However, results were inferior for patients treated with programmed cell death protein 1 (PD-1)/programmed death-ligand 1 (PD-L1) axis inhibitors in the second or subsequent line of therapy. 


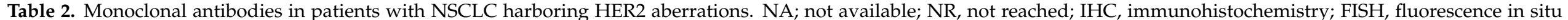

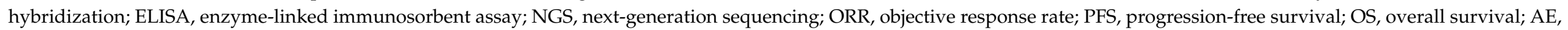
adverse event.

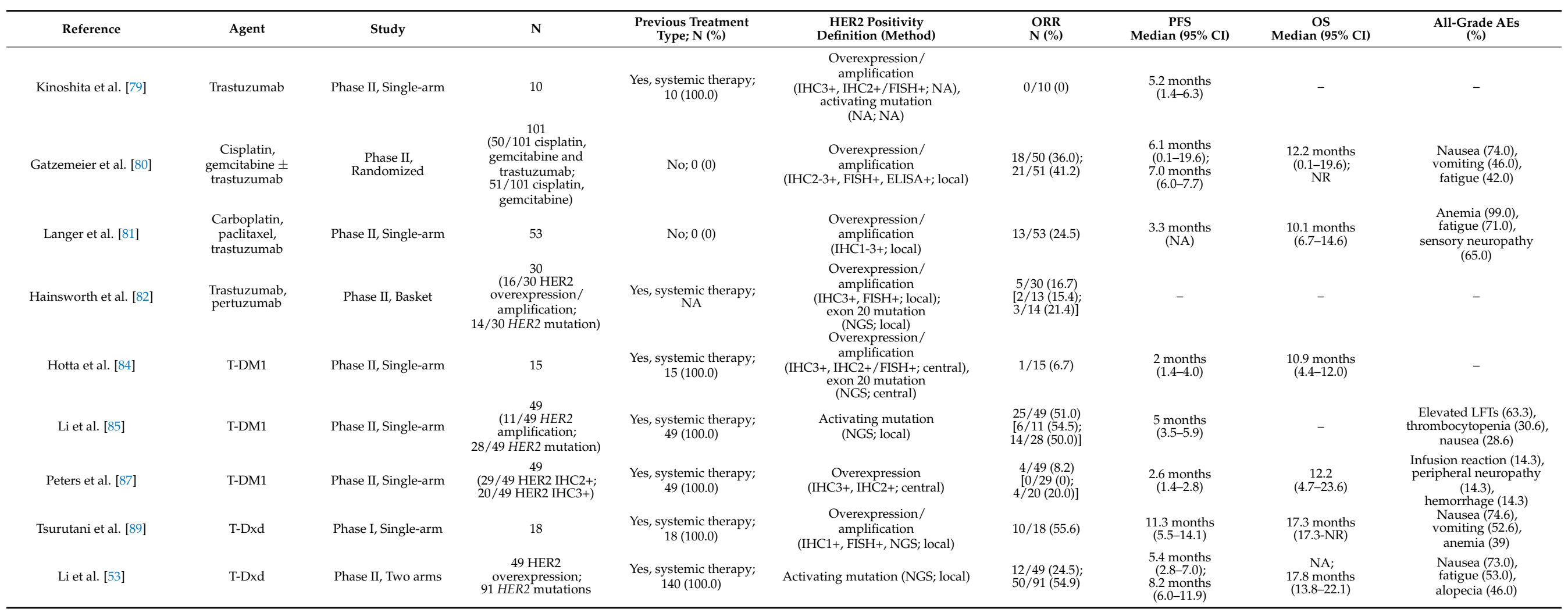


Table 3. Immune checkpoint inhibitors in patients with NSCLC harboring HER2 aberrations. NA; not available; NR, not reached; ICI, immune checkpoint inhibitor; PD-L1, programmed death-ligand 1; ORR, objective response rate; PFS, progression-free survival; OS, overall survival; AE, adverse event.

\begin{tabular}{|c|c|c|c|c|c|c|c|}
\hline Reference & Study & $\mathbf{N}$ & $\begin{array}{l}\text { Line of Treatment, } \\
\text { ICI Regimen }\end{array}$ & $\begin{array}{c}\text { PD-L1 } \\
\text { Expression } \\
\geq 1 / \geq 50(\%) \\
\end{array}$ & $\begin{array}{c}\text { ORR } \\
\text { N (\%) }\end{array}$ & $\begin{array}{c}\text { PFS } \\
\text { Median }(95 \% \text { CI })\end{array}$ & OS \\
\hline Lai et al. [93] & Retrospective & 26 & NA & $\mathrm{NA} / 8.7$ & $3 / 26(11.5)$ & $\begin{array}{l}1.9 \text { months } \\
(1.5-4.0)\end{array}$ & $\begin{array}{l}\text { 10.4 months } \\
\text { (5.9-NR) }\end{array}$ \\
\hline Negrao et al. [94] & Retrospective & 16 & NA & NA/NA & $1 / 16(6.3)$ & $\begin{array}{l}1.8 \text { months } \\
\text { (NA) }\end{array}$ & $\begin{array}{l}17.1 \text { months } \\
\text { (NA) }\end{array}$ \\
\hline Mazieres et al. [95] & Retrospective & 29 & $>1$, monotherapy & $53.3 / 0$ & $2 / 27(7.4)$ & $\begin{array}{l}2.5 \text { months } \\
(1.8-3.5)\end{array}$ & $\begin{array}{l}20.3 \text { months } \\
\text { (7.8-NR) }\end{array}$ \\
\hline Guisier et al. [96] & Retrospective & 23 & $>1$, monotherapy & $17.4 / 4.3$ & $6 / 23(27.3)$ & $\begin{array}{l}2.2 \text { months } \\
(1.7-15.2)\end{array}$ & $\begin{array}{c}20.4 \text { months } \\
(9.3-\mathrm{NR})\end{array}$ \\
\hline Lau et al. [97] & Retrospective & 14 & $>1$, monotherapy & $61.5 / 23.1$ & 4/14 (28.6) & $\begin{array}{l}3.6 \text { months } \\
(1.6-N R)\end{array}$ & NA \\
\hline Saalfeld et al. [98] & Retrospective & 61 & $\begin{array}{c}\text { 1, monotherapy }(5 / 61) \\
1 \text {, combination with } \\
\text { chemotherapy }(22 / 61) \\
>1 \text {, monotherapy } \\
(34 / 61)\end{array}$ & $53.4 / 15.5$ & $\begin{array}{c}\text { 1/5 (20.0); } \\
\text { 11/21 (52.4); } \\
\text { 5/31 (16.1) }\end{array}$ & $\begin{array}{l}\text { NA; } \\
6 \text { months } \\
(6.0-14.0) ; \\
4 \text { months } \\
(4.0-6.0)\end{array}$ & $\begin{array}{c}\text { NA; } \\
\text { NR; } \\
10 \text { months } \\
(6.0-\mathrm{NR})\end{array}$ \\
\hline
\end{tabular}

\section{Conclusions}

As new drug designations rapidly alter the treatment landscape of HER2-mutant NSCLC, several matters still need to be addressed. First, mature OS data as well as phase III trials are expected to confirm the therapeutic benefit from such therapies and compare them with the current standard of care. Second, in an effort to define HER2-mutant disease and determine patterns of response among different HER2 variants, it is imperative that future guidelines advocate for standardized assays for the detection of activating HER2 mutations. In addition, the propensity of HER2-mutant NSCLC for central nervous system (CNS) involvement during the course of treatment will require tailor-made algorithms for the early identification of CNS metastases as well as careful assessment of the intracranial activity of the existing and upcoming anti-HER2 agents. Finally, definitive formulation of the relationship between HER2 amplification/overexpression and activating mutations is urgently needed, since it will inform treatment decisions, including in patients with acquired resistance to EGFR TKIs.

Author Contributions: Conceptualization, I.A.V., K.N.S.; writing—original draft preparation, I.A.V., N.G.; writing—review and editing, I.A.V., A.C., N.G., K.N.S.; supervision, K.N.S. All authors have read and agreed to the published version of the manuscript.

Funding: This research did not receive any specific grant from funding agencies in the public, commercial, or not-for-profit sectors.

Institutional Review Board Statement: Not applicable.

Informed Consent Statement: Not applicable.

Data Availability Statement: Data sharing not applicable.

Conflicts of Interest: The authors declare no conflict of interest.

\section{References}

1. Bargmann, C.; Hung, M.-C.; Weinberg, R.A. The neu oncogene encodes an epidermal growth factor receptor-related protein. Nature 1986, 319, 226-230. [CrossRef]

2. Schechter, A.L.; Stern, D.F.; Vaidyanathan, L.; Decker, S.J.; Drebin, J.A.; Greene, M.I.; Weinberg, R.A. The neu oncogene: An erb-B-related gene encoding a 185,000-Mr tumour antigen. Nature 1984, 312, 513-516. [CrossRef]

3. Slamon, D.J.; Clark, G.M.; Wong, S.G.; Levin, W.J.; Ullrich, A.; McGuire, W.L. Human breast cancer: Correlation of relapse and survival with amplification of the HER-2/neu oncogene. Science 1987, 235, 177-182. [CrossRef]

4. Hynes, N.E.; MacDonald, G. ErbB receptors and signaling pathways in cancer. Curr. Opin. Cell Biol. 2009, 21, 177-184. [CrossRef]

5. Seshadri, R.; Firgaira, F.; Horsfall, D.; McCaul, K.; Setlur, V.; Kitchen, P. Clinical significance of HER-2/neu oncogene amplification in primary breast cancer. The South Australian Breast Cancer Study Group. J. Clin. Oncol. 1993, 11, 1936-1942. [CrossRef]

6. Press, M.F.; Bernstein, L.; Thomas, P.A.; Meisner, L.F.; Zhou, J.-Y.; Ma, Y.; Hung, G.; Robinson, R.A.; Harris, C.; El-Naggar, A. HER-2/neu gene amplification characterized by fluorescence in situ hybridization: Poor prognosis in node-negative breast carcinomas. J. Clin. Oncol. 1997, 15, 2894-2904. [CrossRef] [PubMed] 
7. Eiermann, W.; Group IHS. Trastuzumab combined with chemotherapy for the treatment of HER2-positive metastatic breast cancer: Pivotal trial data. Ann. Oncol. 2001, 12, S57-S62. [CrossRef] [PubMed]

8. Baselga, J.; Tripathy, D.; Mendelsohn, J.; Baughman, S.; Benz, C.C.; Dantis, L.; Sklarin, N.T.; Seidman, A.D.; Hudis, C.A.; Moore, J.; et al. Phase II study of weekly intravenous recombinant humanized anti-p185HER2 monoclonal antibody in patients with HER2/neu-overexpressing metastatic breast cancer. J. Clin. Oncol. 1996, 14, 737-744. [CrossRef]

9. Bang, Y.-J.; Van Cutsem, E.; Feyereislova, A.; Chung, H.C.; Shen, L.; Sawaki, A.; Lordick, F.; Ohtsu, A.; Omuro, Y.; Satoh, T.; et al. Trastuzumab in combination with chemotherapy versus chemotherapy alone for treatment of HER2-positive advanced gastric or gastro-oesophageal junction cancer (ToGA): A phase 3, open-label, randomised controlled trial. Lancet 2010, 376, 687-697. [CrossRef]

10. Yan, M.; Schwaederle, M.; Arguello, D.; Millis, S.Z.; Gatalica, Z.; Kurzrock, R. HER2 expression status in diverse cancers: Review of results from 37,992 patients. Cancer Metastasis Rev. 2015, 34, 157-164. [CrossRef]

11. Oh, D.-Y.; Bang, Y.-J. HER2-targeted therapies-A role beyond breast cancer. Nat. Rev. Clin. Oncol. 2020, 17, 33-48. [CrossRef]

12. Chmielecki, J.; Ross, J.S.; Wang, K.; Frampton, G.M.; Palmer, G.A.; Ali, S.M.; Palma, N.; Morosini, D.; Miller, V.A.; Yelensky, R.; et al. Oncogenic alterations in ERBB2/HER2 represent potential therapeutic targets across tumors from diverse anatomic sites of origin. Oncologist 2015, 20,7-12. [CrossRef]

13. Burgess, A.W.; Cho, H.-S.; Eigenbrot, C.; Ferguson, K.M.; Garrett, T.P.J.; Leahy, D.J.; Lemmon, M.A.; Sliwkowski, M.X.; Ward, C.W.; Yokoyama, S. An Open-and-Shut Case? Recent Insights into the Activation of EGF/ErbB Receptors. Mol. Cell 2003, 12, 541-552. [CrossRef]

14. Kovacs, E.; Zorn, J.A.; Huang, Y.; Barros, T.; Kuriyan, J. A Structural Perspective on the Regulation of the Epidermal Growth Factor Receptor. Annu. Rev. Biochem. 2015, 84, 739-764. [CrossRef] [PubMed]

15. Yarden, Y.; Sliwkowski, M.X. Untangling the ErbB signalling network. Nat. Rev. Mol. Cell Biol. 2001, 2, 127-137. [CrossRef]

16. Citri, A.; Yarden, Y. EGF-ERBB signalling: Towards the systems level. Nat. Rev. Mol. Cell Biol. 2006, 7, 505-516. [CrossRef] [PubMed]

17. Cho, H.-S.; Mason, K.; Ramyar, K.X.; Stanley, A.M.; Gabelli, S.B.; Denney, D.W., Jr.; Leahy, D.J. Structure of the extracellular region of HER2 alone and in complex with the Herceptin Fab. Nature 2003, 421, 756-760. [CrossRef]

18. Garrett, T.P.; McKern, N.M.; Lou, M.; Elleman, T.C.; Adams, T.; Lovrecz, G.O.; Kofler, M.; Jorissen, R.N.; Nice, E.C.; Burgess, A.W.; et al. The Crystal Structure of a Truncated ErbB2 Ectodomain Reveals an Active Conformation, Poised to Interact with Other ErbB Receptors. Mol. Cell 2003, 11, 495-505. [CrossRef]

19. Citri, A.; Skaria, K.B.; Yarden, Y. The deaf and the dumb: The biology of ErbB-2 and ErbB-3. Exp. Cell Res. 2003, 284, 54-65. [CrossRef]

20. Jura, N.; Shan, Y.; Cao, X.; Shaw, D.E.; Kuriyan, J. Structural analysis of the catalytically inactive kinase domain of the human EGF receptor 3. Proc. Natl. Acad. Sci. USA 2009, 106, 21608-21613. [CrossRef]

21. Burstein, H.J. The Distinctive Nature of HER2-Positive Breast Cancers. N. Engl. J. Med. 2005, 353, 1652-1654. [CrossRef] [PubMed]

22. Olayioye, M.A. Intracellular signaling pathways of ErbB2/HER-2 and family members. Breast Cancer Res. 2001, 3, 385. [CrossRef] [PubMed]

23. Moasser, M.M. The oncogene HER2: Its signaling and transforming functions and its role in human cancer pathogenesis. Oncogene 2007, 26, 6469-6487. [CrossRef] [PubMed]

24. Hirsch, F.R.; Varella-Garcia, M.; Franklin, W.A.; Veve, R.; Chen, L.; Helfrich, B.; Zeng, C.; Baron, A.; Bunn, P.A., Jr. Evaluation of HER-2/neu gene amplification and protein expression in non-small cell lung carcinomas. Br. J. Cancer 2002, 86, 1449-1456. [CrossRef]

25. Arcila, M.E.; Chaft, J.; Nafa, K.; Roy-Chowdhuri, S.; Lau, C.; Zaidinski, M.; Paik, P.K.; Zakowski, M.F.; Kris, M.G.; Ladanyi, M. Prevalence, Clinicopathologic Associations, and Molecular Spectrum of ERBB2 (HER2) Tyrosine Kinase Mutations in Lung Adenocarcinomas. Clin. Cancer Res. 2012, 18, 4910-4918. [CrossRef]

26. Rolfo, C.; Russo, A. HER2 Mutations in Non-Small Cell Lung Cancer: A Herculean Effort to Hit the Target. Cancer Discov. 2020, 10, 643-645. [CrossRef] [PubMed]

27. Li, B.T.; Ross, D.S.; Aisner, D.L.; Chaft, J.E.; Hsu, M.; Kako, S.L.; Kris, M.G.; Varella-Garcia, M.; Arcila, M.E. HER2 Amplification and HER2 Mutation Are Distinct Molecular Targets in Lung Cancers. J. Thorac. Oncol. 2016, 11, 414-419. [CrossRef] [PubMed]

28. Wang, S.E.; Narasanna, A.; Perez-Torres, M.; Xiang, B.; Wu, F.Y.; Yang, S.; Carpenter, G.; Gazdar, A.F.; Muthuswamy, S.K.; Arteaga, C.L. HER2 kinase domain mutation results in constitutive phosphorylation and activation of HER2 and EGFR and resistance to EGFR tyrosine kinase inhibitors. Cancer Cell 2006, 10, 25-38. [CrossRef]

29. Cappuzzo, F.; Varella-Garcia, M.; Shigematsu, H.; Domenichini, I.; Bartolini, S.; Ceresoli, G.L.; Rossi, E.; Ludovini, V.; Gregorc, V.; Toschi, L.; et al. Increased HER2 Gene Copy Number Is Associated with Response to Gefitinib Therapy in Epidermal Growth Factor Receptor-Positive Non-Small-Cell Lung Cancer Patients. J. Clin. Oncol. 2005, 23, 5007-5018. [CrossRef] [PubMed]

30. Yu, H.A.; Arcila, M.E.; Rekhtman, N.; Sima, C.S.; Zakowski, M.F.; Pao, W.; Kris, M.G.; Miller, V.A.; Ladanyi, M.; Riely, G.J. Analysis of Tumor Specimens at the Time of Acquired Resistance to EGFR-TKI Therapy in 155 Patients with EGFR-Mutant Lung Cancers. Clin. Cancer Res. 2013, 19, 2240-2247. [CrossRef]

31. Friedlaender, A.; Subbiah, V.; Russo, A.; Banna, G.L.; Malapelle, U.; Rolfo, C.; Addeo, A. EGFR and HER2 exon 20 insertions in solid tumours: From biology to treatment. Nat. Rev. Clin. Oncol. 2021, 1-19. [CrossRef] [PubMed] 
32. Shigematsu, H.; Takahashi, T.; Nomura, M.; Majmudar, K.; Suzuki, M.; Lee, H.; Wistuba, I.I.; Fong, K.M.; Toyooka, S.; Shimizu, N.; et al. Somatic mutations of the HER2 kinase domain in lung adenocarcinomas. Cancer Res. 2005, 65, 1642-1646. [CrossRef]

33. Peters, S.; Zimmermann, S. Targeted therapy in NSCLC driven by HER2 insertions. Transl. Lung Cancer Res. 2014, 3 , 84-88. [CrossRef]

34. Stephens, P.; Hunter, C.; Bignell, G.; Edkins, S.; Davies, H.; Teague, J.; Stevens, C.; O'Meara, S.; Smith, R.; Parker, A.; et al. Lung cancer: Intragenic ERBB2 kinase mutations in tumours. Nature 2004, 431, 525-526. [CrossRef] [PubMed]

35. Zhao, J.; Xia, Y. Targeting HER2 Alterations in Non-Small-Cell Lung Cancer: A Comprehensive Review. JCO Precis. Oncol. 2020, 411-425. [CrossRef]

36. Perera, S.A.; Li, D.; Shimamura, T.; Raso, M.G.; Ji, H.; Chen, L.; Borgman, C.L.; Zaghlul, S.; Brandstetter, K.A.; Kubo, S.; et al. HER2YVMA drives rapid development of adenosquamous lung tumors in mice that are sensitive to BIBW2992 and rapamycin combination therapy. Proc. Natl. Acad. Sci. USA 2009, 106, 474-479. [CrossRef]

37. Yamamoto, H.; Higasa, K.; Sakaguchi, M.; Shien, K.; Soh, J.; Ichimura, K.; Furukawa, M.; Hashida, S.; Tsukuda, K.; Takigawa, N.; et al. Novel Germline Mutation in the Transmembrane Domain of HER2 in Familial Lung Adenocarcinomas. J. Natl. Cancer Inst. 2013, 106, djt338. [CrossRef]

38. Greulich, H.; Kaplan, B.; Mertins, P.; Chen, T.-H.; Tanaka, K.E.; Yun, C.-H.; Zhang, X.; Lee, S.-H.; Cho, J.; Ambrogio, L.; et al. Functional analysis of receptor tyrosine kinase mutations in lung cancer identifies oncogenic extracellular domain mutations of ERBB2. Proc. Natl. Acad. Sci. USA 2012, 109, 14476. [CrossRef]

39. Collisson, E.A.C.J.; Campbell, J.; Brooks, A.; Berger, A.; Lee, W.; Chmielecki, J.; Beer, D.; Cope, L.; Creighton, C.; Danilova, L.; et al. Comprehensive molecular profiling of lung adenocarcinoma. Nature 2014, 511, 543-550.

40. Heinmöller, P.; Gross, C.; Beyser, K.; Schmidtgen, C.; Maass, G.; Pedrocchi, M.; Rüschoff, J. HER2 status in non-small cell lung cancer: Results from patient screening for enrollment to a phase II study of herceptin. Clin. Cancer Res. 2003, 9, 5238-5243. [CrossRef]

41. Takeda, M.; Sakai, K.; Hayashi, H.; Tanaka, K.; Tanizaki, J.; Takahama, T.; Haratani, K.; Nishio, K.; Nakagawa, K. Clinical characteristics of non-small cell lung cancer harboring mutations in exon 20 of EGFR or HER2. Oncotarget 2018, 9, 21132-21140. [CrossRef] [PubMed]

42. Ninomiya, K.; Hata, T.; Yoshioka, H.; Ohashi, K.; Bessho, A.; Hosokawa, S.; Ishikawa, N.; Yamasaki, M.; Shibayama, T.; Aoe, K.; et al. A Prospective Cohort Study to Define the Clinical Features and Outcome of Lung Cancers Harboring HER2 Aberration in Japan (HER2-CS STUDY). Chest 2019, 156, 357-366. [CrossRef]

43. Takezawa, K.; Pirazzoli, V.; Arcila, M.E.; Nebhan, C.A.; Song, X.; De Stanchina, E.; Ohashi, K.; Janjigian, Y.Y.; Spitzler, P.J.; Melnick, M.A.; et al. HER2 Amplification: A Potential Mechanism of Acquired Resistance to EGFR Inhibition in EGFR-Mutant Lung Cancers That Lack the Second-Site EGFRT790M Mutation. Cancer Discov. 2012, 2, 922-933. [CrossRef] [PubMed]

44. Ohashi, K.; Maruvka, Y.E.; Michor, F.; Pao, W. Epidermal Growth Factor Receptor Tyrosine Kinase Inhibitor-Resistant Disease. J. Clin. Oncol. 2013, 31, 1070-1080. [CrossRef] [PubMed]

45. Ohashi, K.; Ninomiya, K.; Yoshioka, H.; Bessho, A.; Shibayama, T.; Aoe, K.; Ishikawa, N.; Kozuki, T.; Kawai, H.; Kuyama, S.; et al. Impact of HER2 expression on EGFR-TKI treatment outcomes in lung tumors harboring EGFR mutations: A HER2-CS study subset analysis. Lung Cancer 2020, 150, 83-89. [CrossRef] [PubMed]

46. Wolff, A.C.; Hammond, M.E.H.; Allison, K.H.; Harvey, B.E.; Mangu, P.B.; Bartlett, J.M.S.; Bilous, M.; Ellis, I.O.; Fitzgibbons, P.; Hanna, W.; et al. Human Epidermal Growth Factor Receptor 2 Testing in Breast Cancer: American Society of Clinical Oncology/College of American Pathologists Clinical Practice Guideline Focused Update. Arch. Pathol. Lab. Med. 2018, 142, 1364-1382. [CrossRef] [PubMed]

47. Bartley, A.N.; Washington, M.K.; Ventura, C.B.; Ismaila, N.; Colasacco, C.; Benson, A.B., III; Carrato, A.; Gulley, M.L.; Jain, D.; Kakar, S.; et al. HER2 Testing and Clinical Decision Making in Gastroesophageal Adenocarcinoma: Guideline from the College of American Pathologists, American Society for Clinical Pathology, and the American Society of Clinical Oncology. J. Clin. Oncol. 2017, 35, 446-464. [CrossRef]

48. Jørgensen, J.T.; Winther, H.; Askaa, J.; Andresen, L.; Olsen, D.; Mollerup, J. A Companion Diagnostic with Significant Clinical Impact in Treatment of Breast and Gastric Cancer. Front. Oncol. 2021, 11, 676939. [CrossRef] [PubMed]

49. Hotta, K.; Yanai, H.; Ohashi, K.; Ninomiya, K.; Nakashima, H.; Kayatani, H.; Takata, M.; Kiura, K. Pilot evaluation of a HER2 testing in non-small-cell lung cancer. J. Clin. Pathol. 2019, 73, 353-357. [CrossRef]

50. Yoshizawa, A.; Sumiyoshi, S.; Sonobe, M.; Kobayashi, M.; Uehara, T.; Fujimoto, M.; Tsuruyama, T.; Date, H.; Haga, H. HER2 status in lung adenocarcinoma: A comparison of immunohistochemistry, fluorescence in situ hybridization (FISH), dual-ISH, and gene mutations. Lung Cancer 2020, 85, 373-378. [CrossRef] [PubMed]

51. Suzuki, M.; Shiraishi, K.; Yoshida, A.; Shimada, Y.; Suzuki, K.; Asamura, H.; Furuta, K.; Kohno, T.; Tsuta, K. HER2 gene mutations in non-small cell lung carcinomas: Concurrence with her2 gene amplification and her2 protein expression and phosphorylation. Lung Cancer 2015, 87, 14-22. [CrossRef] [PubMed]

52. Elamin, Y.Y.; Robichaux, J.P.; Carter, B.W.; Altan, M.; Gibbons, D.L.; Fossella, F.V.; Lam, V.K.; Patel, A.B.; Negrao, M.V.; Le, X.; et al. Poziotinib for Patients with HER2 Exon 20 Mutant Non-Small-Cell Lung Cancer: Results from a Phase II Trial. J. Clin. Oncol. 2021. [CrossRef]

53. Li, B.T.; Smit, E.F.; Goto, Y.; Nakagawa, K.; Udagawa, H.; Mazières, J.; Nagasaka, M.; Bazhenova, L.; Saltos, A.N.; Felip, E.; et al. Trastuzumab Deruxtecan in HER2-Mutant Non-Small-Cell Lung Cancer. N. Engl. J. Med. 2021. [CrossRef] [PubMed] 
54. De Grève, J.; Moran, T.; Graas, M.P.; Galdermans, D.; Vuylsteke, P.; Canon, J.L.; Schallier, D.; Decoster, L.; Teugels, E.; Massey, D.; et al. Phase II study of afatinib, an irreversible ErbB family blocker, in demographically and genotypically defined lung adenocarcinoma. Lung Cancer 2015, 88, 63-69. [CrossRef]

55. Peters, S.; Curioni-Fontecedro, A.; Nechushtan, H.; Shih, J.-Y.; Liao, W.-Y.; Gautschi, O.; Spataro, V.; Unk, M.; Yang, J.C.-H.; Lorence, R.M.; et al. Activity of Afatinib in Heavily Pretreated Patients with ERBB2 Mutation-Positive Advanced NSCLC: Findings From a Global Named Patient Use Program. J. Thorac. Oncol. 2018, 13, 1897-1905. [CrossRef]

56. Dziadziuszko, R.; Smit, E.F.; Dafni, U.; Wolf, J.; Wasag, B.; Biernat, W.; Finn, S.P.; Kammler, R.; Tsourti, Z.; Rabaglio, M.; et al. Afatinib in NSCLC With HER2 Mutations: Results of the Prospective, Open-Label Phase II NICHE Trial of European Thoracic Oncology Platform (ETOP). J. Thorac. Oncol. 2019, 14, 1086-1094. [CrossRef] [PubMed]

57. Fan, Y.; Chen, J.; Zhou, C.; Wang, H.; Shu, Y.; Zhang, J.; Hua, H.; Huang, D.C.-L.; Zhou, C. Afatinib in patients with advanced non-small cell lung cancer harboring HER2 mutations, previously treated with chemotherapy: A phase II trial. Lung Cancer 2020, 147, 209-213. [CrossRef]

58. Engelman, J.A.; Zejnullahu, K.; Gale, C.-M.; Lifshits, E.; Gonzales, A.J.; Shimamura, T.; Zhao, F.; Vincent, P.W.; Naumov, G.N.; Bradner, J.E.; et al. PF00299804, an Irreversible Pan-ERBB Inhibitor, Is Effective in Lung Cancer Models with EGFR and ERBB2 Mutations that Are Resistant to Gefitinib. Cancer Res. 2007, 67, 11924-11932. [CrossRef]

59. Jänne, P.A.; Boss, D.S.; Camidge, D.R.; Britten, C.D.; Engelman, J.A.; Garon, E.B.; Guo, F.; Wong, S.; Liang, J.; Letrent, S.; et al. Phase I Dose-Escalation Study of the Pan-HER Inhibitor, PF299804, in Patients with Advanced Malignant Solid Tumors. Clin. Cancer Res. 2011, 17, 1131-1139. [CrossRef]

60. Kris, M.G.; Camidge, D.R.; Giaccone, G.; Hida, T.; Li, B.; O'Connell, J.; Taylor, I.; Zhang, H.; Arcila, M.E.; Goldberg, Z.; et al. Targeting HER2 aberrations as actionable drivers in lung cancers: Phase II trial of the pan-HER tyrosine kinase inhibitor dacomitinib in patients with HER2-mutant or amplified tumors. Ann. Oncol. 2015, 26, 1421-1427. [CrossRef]

61. Nagano, M.; Kohsaka, S.; Ueno, T.; Kojima, S.; Saka, K.; Iwase, H.; Kawazu, M.; Mano, H. High-Throughput Functional Evaluation of Variants of Unknown Significance in ERBB2. Clin. Cancer Res. 2018, 24, 5112-5122. [CrossRef]

62. Ivanova, E.; Kuraguchi, M.; Xu, M.; Portell, A.; Taus, L.; Diala, I.; Lalani, A.S.; Choi, J.; Chambers, E.S.; Li, S.; et al. Use of ExVivo Patient-Derived Tumor Organotypic Spheroids to Identify Combination Therapies for HER2 Mutant Non-Small Cell Lung Cancer. Clin. Cancer Res. 2020, 26, 2393-2403. [CrossRef]

63. Hyman, D.M.; Piha-Paul, S.A.; Won, H.; Rodon, J.; Saura, C.; Shapiro, G.I.; Juric, D.; Quinn, D.I.; Moreno, V.; Doger, B.; et al. HER kinase inhibition in patients with HER2- and HER3-mutant cancers. Nature 2018, 554, 189-194. [CrossRef] [PubMed]

64. Robichaux, J.P.; Elamin, Y.Y.; Tan, Z.; Carter, B.W.; Zhang, S.; Liu, S.; Li, S.; Chen, T.; Poteete, A.; Estrada-Bernal, A.; et al. Mechanisms and clinical activity of an EGFR and HER2 exon 20-selective kinase inhibitor in non-small cell lung cancer. Nat. Med. 2018, 24, 638-646. [CrossRef]

65. Kim, T.M.; Lee, K.-W.; Oh, D.-Y.; Lee, J.-S.; Im, S.-A.; Kim, D.-W.; Han, S.-W.; Kim, T.-Y.; Kim, J.H.; Han, H.; et al. Phase 1 Studies of Poziotinib, an Irreversible Pan-HER Tyrosine Kinase Inhibitor in Patients with Advanced Solid Tumors. Cancer Res. Treat. 2018, 50, 835-842. [CrossRef] [PubMed]

66. Robichaux, J.P.; Elamin, Y.Y.; Vijayan, R.S.K.; Nilsson, M.B.; Hu, L.; He, J.; Zhang, F.; Pisegna, M.; Poteete, A.; Sun, H.; et al. Pan-Cancer Landscape and Analysis of ERBB2 Mutations Identifies Poziotinib as a Clinically Active Inhibitor and Enhancer of T-DM1 Activity. Cancer Cell 2019, 36, 444-457.e7. [CrossRef] [PubMed]

67. Socinski, M.A.; Cornelissen, R.; Garassino, M.C.; Clarke, J.; Tchekmedyian, N.; Molina, J.; Goldman, J.W.; Bhat, G.; Lebel, F.; Le, X. LBA60-ZENITH20, a multinational, multi-cohort phase II study of poziotinib in NSCLC patients with EGFR or HER2 exon 20 insertion mutations. Ann. Oncol. 2020, 31, S1142-S1215. [CrossRef]

68. Le, X.; Cornelissen, R.; Garassino, M.; Clarke, J.M.; Tchekmedyian, N.; Goldman, J.W.; Leu, S.Y.; Bhat, G.; Lebel, F.; Heymach, J.V.; et al. Poziotinib in Non-Small-Cell Lung Cancer Harboring HER2 Exon 20 Insertion Mutations After Prior Therapies: ZENITH20-2 Trial. J. Clin. Oncol. 2021. [CrossRef]

69. Cornelissen, R.; Sun, S.; Wollner, M.; Garassino, M.C.C.; Prelaj, A.; Haura, E.B.; Piotrowska, Z.; Goldman, J.W.; Socinski, M.; Dreling, L.; et al. LBA46-Efficacy and safety of poziotinib in treatment-naïve NSCLC harboring HER2 exon 20 mutations: A multinational phase II study (ZENITH20-4). Ann. Oncol. 2021, 32, S1283-S1346. [CrossRef]

70. Prelaj, A.; Bottiglieri, A.; Proto, C.; Russo, G.L.; Signorelli, D.; Ferrara, R.; Galli, G.; De Toma, A.; Viscardi, G.; Brambilla, M.; et al. Poziotinib for EGFR and HER2 exon 20 insertion mutation in advanced NSCLC: Results from the expanded access program. Eur. J. Cancer 2021, 149, 235-248. [CrossRef]

71. Kosaka, T.; Tanizaki, J.; Paranal, R.M.; Endoh, H.; Lydon, C.; Capelletti, M.; Repellin, C.E.; Choi, J.; Ogino, A.; Calles, A.; et al. Response heterogeneity of EGFR and HER2 exon 20 insertions to covalent EGFR and HER2 inhibitors. Cancer Res. 2017, 77, 2712-2721. [CrossRef]

72. Wang, Y.; Jiang, T.; Qin, Z.; Jiang, J.; Wang, Q.; Yang, S.; Rivard, C.; Gao, G.; Ng, T.; Tu, M.; et al. HER2 exon 20 insertions in non-small-cell lung cancer are sensitive to the irreversible pan-HER receptor tyrosine kinase inhibitor pyrotinib. Ann. Oncol. 2019, 30, 447-455. [CrossRef]

73. Zhou, C.; Li, X.; Wang, Q.; Gao, G.; Zhang, Y.; Chen, J.; Shu, Y.; Hu, Y.; Fan, Y.; Fang, J.; et al. Pyrotinib in HER2-Mutant Advanced Lung Adenocarcinoma After Platinum-Based Chemotherapy: A Multicenter, Open-Label, Single-Arm, Phase II Study. J. Clin. Oncol. 2020, 38, 2753-2761. [CrossRef] 
74. Estrada-Bernal, A.; Le, A.T.; Doak, A.E.; Tirunagaru, V.G.; Silva, S.; Bull, M.R.; Smaill, J.B.; Patterson, A.V.; Kim, C.; Liu, S.V.; et al. Tarloxotinib Is a Hypoxia-Activated Pan-HER Kinase Inhibitor Active Against a Broad Range of HER-Family Oncogenes. Clin. Cancer Res. 2021, 27, 1463-1475. [CrossRef]

75. Liu, S.V.; Villaruz, L.C.; Lee, V.H.F.; Zhu, V.W.; Baik, C.S.; Sacher, A.; McCoach, C.E.; Nguyen, D.; Li, J.C.; Pacheco, J.M.; et al. LBA61 First analysis of RAIN-701: Study of tarloxotinib in patients with non-small cell lung cancer (NSCLC) EGFR Exon 20 insertion, HER2-activating mutations \& other solid tumours with NRG1/ERBB gene fusions. Ann. Oncol. 2020, 31, S1189.

76. Han, H.; Li, S.; Chen, T.; Fitzgerald, M.; Liu, S.; Peng, C.; Tang, K.H.; Cao, S.; Chouitar, J.; Wu, J.; et al. Targeting HER2 Exon 20 Insertion-Mutant Lung Adenocarcinoma with a Novel Tyrosine Kinase Inhibitor Mobocertinib. Cancer Res. 2021, 81, 5311-5324. [CrossRef]

77. Zhou, C.; Ramalingam, S.S.; Kim, T.M.; Kim, S.W.; Yang, J.C.; Riely, G.J.; Mekhail, T.; Nguyen, D.; Garcia Campelo, M.R.; Felip, E.; et al. Treatment Outcomes and Safety of Mobocertinib in Platinum-Pretreated Patients with EGFR Exon 20 InsertionPositive Metastatic Non-Small Cell Lung Cancer: A Phase 1/2 Open-label Nonrandomized Clinical Trial. JAMA Oncol. 2021, 7, e214761. [CrossRef]

78. Hudis, C.A. Trastuzumab-Mechanism of Action and Use in Clinical Practice. N. Engl. J. Med. 2007, 357, 39-51. [CrossRef]

79. Kinoshita, I.; Goda, T.; Watanabe, K.; Maemondo, M.; Oizumi, S.; Amano, T.; Hatanaka, Y.; Matsuno, Y.; Nishihara, H.; Asahina, H.; et al. A phase II study of trastuzumab monotherapy in pretreated patientswith non-small cell lung cancers (NSCLCs) harboring HER2 alterations:HOT1303-B trial. Ann. Oncol. 2018, 29, VIII540. [CrossRef]

80. Gatzemeier, U.; Groth, G.; Butts, C.; Van Zandwijk, N.; Shepherd, F.; Ardizzoni, A.; Barton, C.; Ghahramani, P.; Hirsh, V. Randomized phase II trial of gemcitabine-cisplatin with or without trastuzumab in HER2-positive non-small-cell lung cancer. Ann. Oncol. 2004, 15, 19-27. [CrossRef]

81. Langer, C.J.; Stephenson, P.; Thor, A.; Vangel, M.; Johnson, D.H. Trastuzumab in the Treatment of Advanced Non-Small-Cell Lung Cancer: Is There a Role? Focus on Eastern Cooperative Oncology Group Study 2598. J. Clin. Oncol. 2004, 22, 1180-1187. [CrossRef]

82. Hainsworth, J.D.; Meric-Bernstam, F.; Swanton, C.; Hurwitz, H.; Spigel, D.R.; Sweeney, C.; Burris, H.A.; Bose, R.; Yoo, B.; Stein, A.; et al. Targeted Therapy for Advanced Solid Tumors on the Basis of Molecular Profiles: Results from MyPathway, an Open-Label, Phase IIa Multiple Basket Study. J. Clin. Oncol. 2018, 36, 536-542. [CrossRef]

83. Lewis Phillips, G.D.; Li, G.; Dugger, D.L.; Crocker, L.M.; Parsons, K.L.; Mai, E.; Blättler, W.A.; Lambert, J.M.; Chari, R.V.; Lutz, R.J.; et al. Targeting HER2-positive breast cancer with trastuzumab-DM1, an antibody-cytotoxic drug conjugate. Cancer Res. 2008, 68, 9280-9290. [CrossRef]

84. Hotta, K.; Aoe, K.; Kozuki, T.; Ohashi, K.; Ninomiya, K.; Ichihara, E.; Kubo, T.; Ninomiya, T.; Chikamori, K.; Harada, D.; et al. A Phase II Study of Trastuzumab Emtansine in HER2-Positive Non-Small Cell Lung Cancer. J. Thorac. Oncol. 2018, 13, 273-279. [CrossRef]

85. Li, B.T.; Shen, R.; Buonocore, D.; Olah, Z.T.; Ni, A.; Ginsberg, M.S.; Ulaner, G.A.; Offin, M.; Feldman, D.; Hembrough, T.; et al. Ado-Trastuzumab Emtansine for Patients with HER2-Mutant Lung Cancers: Results from a Phase II Basket Trial. J. Clin. Oncol. 2018, 36, 2532-2537. [CrossRef]

86. Li, B.T.; Michelini, F.; Misale, S.; Cocco, E.; Baldino, L.; Cai, Y.; Shifman, S.; Tu, H.-Y.; Myers, M.L.; Xu, C.; et al. HER2-Mediated Internalization of Cytotoxic Agents in ERBB2 Amplified or Mutant Lung Cancers. Cancer Discov. 2020, 10, 674-687. [CrossRef]

87. Peters, S.; Stahel, R.; Bubendorf, L.; Bonomi, P.; Villegas, A.; Kowalski, D.M.; Baik, C.S.; Isla, D.; Carpeno, J.C.; Garrido, P.; et al. Trastuzumab Emtansine (T-DM1) in Patients with Previously Treated HER2-Overexpressing Metastatic Non-Small Cell Lung Cancer: Efficacy, Safety, and Biomarkers. Clin. Cancer Res. 2019, 25, 64-72. [CrossRef]

88. Ogitani, Y.; Aida, T.; Hagihara, K.; Yamaguchi, J.; Ishii, C.; Harada, N.; Soma, M.; Okamoto, H.; Oitate, M.; Arakawa, S.; et al. DS-8201a, A Novel HER2-Targeting ADC with a Novel DNA Topoisomerase I Inhibitor, Demonstrates a Promising Antitumor Efficacy with Differentiation from T-DM1. Clin. Cancer Res. 2016, 22, 5097-5108. [CrossRef]

89. Tsurutani, J.; Iwata, H.; Krop, I.; Jänne, P.A.; Doi, T.; Takahashi, S.; Park, H.; Redfern, C.; Tamura, K.; Wise-Draper, T.M.; et al. Targeting HER2 with Trastuzumab Deruxtecan: A Dose-Expansion, Phase I Study in Multiple Advanced Solid Tumors. Cancer Discov. 2020, 10, 688-701. [CrossRef]

90. Riudavets, M.; Sullivan, I.; Abdayem, P.; Planchard, D. Targeting HER2 in non-small-cell lung cancer (NSCLC): A glimpse of hope? An updated review on therapeutic strategies in NSCLC harbouring HER2 alterations. ESMO Open 2021, 6. [CrossRef]

91. Dong, Z.-Y.; Zhang, J.-T.; Liu, S.-Y.; Su, J.; Zhang, C.; Xie, Z.; Zhou, Q.; Tu, H.-Y.; Xu, C.-R.; Si-Yang, L.; et al. EGFR mutation correlates with uninflamed phenotype and weak immunogenicity, causing impaired response to PD-1 blockade in non-small cell lung cancer. OncoImmunology 2017, 6, e1356145. [CrossRef]

92. Reuben, A.; Zhang, J.; Chiou, S.-H.; Gittelman, R.M.; Li, J.; Lee, W.-C.; Fujimoto, J.; Behrens, C.; Liu, X.; Wang, F.; et al. Comprehensive $\mathrm{T}$ cell repertoire characterization of non-small cell lung cancer. Nat. Commun. 2020, 11, 603. [CrossRef] [PubMed]

93. Lai, W.V.; Feldman, D.L.; Buonocore, D.J.; Brzostowski, E.B.; Rizvi, H.; Plodkowski, A.J.; Ni, A.; Sabari, J.K.; Offin, M.D.; Kris, M.G.; et al. PD-L1 expression, tumor mutation burden and response to immune checkpoint blockade in patients with HER2-mutant lung cancers. J. Clin. Oncol. 2018, 36, 9060. [CrossRef]

94. Negrao, M.V.; Skoulidis, F.; Montesion, M.; Schulze, K.; Bara, I.; Shen, V.; Xu, H.; Hu, S.; Sui, D.; Elamin, Y.Y.; et al. Oncogenespecific differences in tumor mutational burden, PD-L1 expression, and outcomes from immunotherapy in non-small cell lung cancer. J. Immunother. Cancer 2021, 9, e002891. [CrossRef] 
95. Mazieres, J.; Drilon, A.; Lusque, A.; Mhanna, L.; Cortot, A.; Mezquita, L.; Thai, A.; Mascaux, C.; Couraud, S.; Veillon, R.; et al. Immune checkpoint inhibitors for patients with advanced lung cancer and oncogenic driver alterations: Results from the Immunotarget registry. Ann. Oncol. 2019, 30, 1321-1328. [CrossRef]

96. Guisier, F.; Dubos-Arvis, C.; Viñas, F.; Doubre, H.; Ricordel, C.; Ropert, S.; Janicot, H.; Bernardi, M.; Fournel, P.; Lamy, R.; et al. Efficacy and Safety of Anti-PD-1 Immunotherapy in Patients with Advanced NSCLC With BRAF, HER2, or MET Mutations or RET Translocation: GFPC 01-2018. J. Thorac. Oncol. 2020, 15, 628-636. [CrossRef]

97. Lau, S.C.; Fares, A.F.; Le, L.W.; Mackay, K.M.; Soberano, S.; Chan, S.W.; Smith, E.; Ryan, M.; Tsao, M.S.; Bradbury, P.A.; et al. Subtypes of EGFR- and HER2-Mutant Metastatic NSCLC Influence Response to Immune Checkpoint Inhibitors. Clin. Lung Cancer 2021, 22, 253-259. [CrossRef]

98. Saalfeld, F.C.; Wenzel, C.; Christopoulos, P.; Merkelbach-Bruse, S.; Reissig, T.M.; Laßmann, S.; Thiel, S.; Stratmann, J.A.; Marienfeld, R.; Berger, J.; et al. Efficacy of Immune Checkpoint Inhibitors Alone or in Combination with Chemotherapy in NSCLC Harboring ERBB2 Mutations. J. Thorac. Oncol. 2021, 16, 1952-1958. [CrossRef] 